\title{
Military Interventions in International Law and Practices: Objectives, Legality and Legitimacy
}

\author{
Ahmed Naji Mohammed Al-hanhanah* Maming Fei \\ Dalian Maritime University, Administration Building, School of Law, Industrial Zone, No. 1 Linghai Road, \\ 116026, Ganjingzi District, Dalian, China
}

\begin{abstract}
Military intervention is defined as forcible meddling in state affairs. This intervention can take many different forms, including political or military action, as well as direct or indirect intervention. International law is largely concerned with the prohibition of dictatorial or coercive meddling in state affairs. Military intervention has piqued scholarly attention since the Cold War's conclusion, and it has been proven that various cases of the usage of force or the menace to apply force were lawful in the lack of a Security Council resolution. Nonetheless, since the Cold War's end, issues of dominance and non-intervention have been called into question by the emerging human rights rhetoric, which has used the benefit of the big powers to engage in the concerns of weaker nations. Through the Charter of the UN, it is clear that the international military intervention under Chapter VII is not an advantage to the Security Council Rather; it is a legal obligation subject to international law to attain safety and harmony for all the peoples in this world. Through the Charter of the UN also, must respect the aims and rules of international law when deciding military intervention against a state or entity in the international community away from the political objectives that achieve the interests of powerful countries. The decision to engage in military intervention against a non-state entity or another state is a tough and complex one that involves a plethora of moral, political, legal, economical, and logistical concerns for a state to measure. Therefore, this research focused on the military intervention in international law and practices, study provided a comprehensive and specialized legal study on military intervention subject, in which study provides analysis on the historical background, types, objectives, legality and legitimacy of military intervention in international law comparable with international practice and make proposals to develop a clear legal framework for military intervention to ensure the realization of the main objectives of military intervention that set in UN Charter and international law away from the influence of the majors' powers that aim to achieve their own goals through military intervention within the framework of the UNSC.
\end{abstract}

Keywords: Military Intervention, International Law, International Practice, UN Charter, International Peace and Security.

DOI: $10.7176 / \mathrm{JLPG} / 117-04$

Publication date: January $31^{\text {st }} 2022$

\section{Introduction}

Military interventions in operation are defined as "the movement of regular troops or forces (airborne, seaborne, shelling, etc.) of one country inside another, in the context of some political issue or dispute" ${ }^{1}$. Punitive intervention actually verified in the 1990s but it started in the late 1980s, the first instance was the United States' airstrike on Libya in 1986. The United States' missile attacks on Iraq in 1993, as well as on locations in Sudan and Afghanistan in 1998, sparked considerable new interventionist discussions ${ }^{2}$. Because of unilateral statecentered interventions, these attacks sparked new debates over the legitimizing effect of interventions, resulting in the discussions of modern interventionist. Humanitarian intervention, whether multilateral or unilateral in nature, turned into important in upcoming discussion on intervention's polemics. Following the events of September 11, 2001 (9/11), there appears to have been another important shift in which the focus appears to have shifted back to military action. For some, this new activism represents a globalization of the human conscience, which has been long overdue; for others, it represents an unsettling violation of an international system based on state sovereignty and the sanctity of their zone. For some, the only significant difficulty is guaranteeing that involuntary interventions are operative; for others, debates concerning the legality procedure and the potential misapplication of law practice play a larger role. This dispute exposed some major schisms in the worldwide society. In the 1990s, the growth of new forms of intervention like combating terrorism, humanitarian interventions and defending democracy were accompanied by the decline of other intervention patterns ${ }^{1}$. In fact, most patterns of military involvement have been abandoned in favour of combating terrorism and defending democracy ${ }^{3}$.

Next to the Cold War, it became increasingly obvious that the worldwide legal structure leading the usage of force among states, as preserved in the UN Charter is incapable of successfully responding to contemporary challenges to global harmony and safety. With the biological, chemical, and nuclear weapons propagation; largescale human rights violations comprising crimes against genocide and humanity; well-planned and equipped non-state actors like terrorist and soldiers groups are all contributing factors, the situation is particularly dire. 
Furthermore, over the last few years, the human rights discourse has grown at a rapid speed. The global community has now largely acknowledged that independent nations have a responsibility to guard their citizen from egregious human rights desecrations and, as a result, to abstain from committing such crimes. As an outcome, the idea of state sovereignty is changed from the view of a nation to be the exclusive chief of its internal affairs, and recognising the claim to sovereignty. The accompanying non-interference rights are premised on a state's effective performance of responsibilities as strong-minded by the international society, particularly the safeguarding of essential human rights. The global community is obligated to act in response and apply the necessary means once a state un-able to meet its obligations, which may eventually comprise the usage of military force to restore global harmony and safety or to prevent severe human rights breaches from occurring. As an outcome, there is an obvious conflict among the prohibition on using force contrary to countries, the principle of non-interference in the internal affairs of nations, safeguarding and promoting human right and restoring global harmony and safety. This is a tension that the international community has not entirely resolved, as seen by the extensive debates and criticisms in this area by the existing nation of international law. According to the preceding, it is clear that the judgment to involve in military intervention contrary to a non-state entity or another state is a tough and complex one that involves a plethora of moral, political, legal, economical, and logistical concerns when framing policies and implementing decisions regarding military intervention.

Military intervention has attracted much scholarly interest but has not received adequate attention from legal researchers in comparison to researches that conducted by journalists and politicians on the effect of military intervention on intercontinental relations and human rights, or from a moral humanitarian perspective. Therefore, this study will be a comprehensive and specialized legal study on military intervention subject, which will analyse the historical background, types, objectives, legality and legitimacy of military intervention in international law compared with international practice and make proposals to develop a clear legal framework for military intervention to ensure the realization of the main objectives of military intervention that set in the international law and UN Charter away from the influence of the majors' powers that aim to achieve their own goals through military intervention within the framework of the UNSC. In the following sections study begun by examining the historical background of military intervention, conceptual framework and classifications of military intervention, and then move on to examining the objectives of military interventions. Lastly, the study discussed the legality and legitimacy of military intervention.

\section{Historical Background of Military Intervention}

\subsection{The Military Intervention under middle Ages}

Evidence indicates that even before the pre-Roman era, cultures governed the conditions under which force might be used. Formal "just war" emerged in the Roman era, although at the time it was more concerned with enforcing rules of procedure than with justifying the use of military force on moral grounds. Lawful justifications for war were emphasized by Christians and Muslims who felt that 'God had decreed' every conflict to be unquestionably just ${ }^{4}$. As a legitimate response to the other side's illegal actions, war was called for. However, it had to be proportional to the extent of the illegality of the enemy's actions to be considered restitution ${ }^{5}$.

\subsection{The Military Intervention under League of Nations}

Since ancient times, the idea of creating a world body through which disputes between states can be settled amicably has been raised. After the collapse of the Pact of Europe and after World War I (1914-1918), the League of Nations was founded in 1919 and was the first modern organization of the collective security system. An idea that war may be used as a last resort to enforce legal rights if negotiations failed developed between the Vienna Conference's last act in 1815 and the founding of The League of Nations in 1919. The tremendous devastation of World War One (WWI) played a key role in this complete change in attitudes about war. In order to create the legal framework for carrying out the mission of the League of Nations, the members included a special clause in the charter they signed. Article 10 of the League of Nations states: "The Members of the League undertake to respect and preserve as against external aggression the territorial integrity and existing political independence of all Members of the League. In case of any such aggression or in case of any threat or danger of such aggression the Council shall advise upon the means by which this obligation shall be fulfilled. However, movements toward peaceful conflict resolution have been hampered by state policies that continue to emphasize a limitless right to go to war as an attribute of sovereignty ${ }^{6}$. The League of Nations Charter of 1919 featured with formalities that imposed some limitations on usage of force, but they didn't fully forbid these actions from occurring. Kellogg-Briand Treaty or the Pact of Paris was signed in 1928, another significant breakthrough occurred ${ }^{7}$, members of this pact agreed that only peaceful tactics should be used to settle disagreements. This agreement was requisite on 63 countries, condemned the "recourse to war for the solution of international disputes" did not fully forbid completely the use of force. The Paris Pact affected the ensuing legal structure for the use of force and it appears to be still in place ${ }^{8}$. In theory, although the charter gave the League 
of Nations the right to use military force, it had no force at its disposal; So in the end, there was nothing the League could do if any nation violated the terms of the charter and used force through military intervention. The necessary conditions that the League of Nations failed to implement are; First, the obligation of states to renounce the use of force for any purpose other than defending their territorial sovereignty. Second, that all states agree on a clear definition of aggression so that measures can be taken to prevent or counteract it. Third, the obligation of states, especially the great powers, to place their armed forces at the disposal of the international institution for the prevention of aggression, away from their immediate interests. Fourth, the obligation of all states to prevent any violations of sanctions that would help outlaws. This is what the United Nations tried to achieve after World War II in 1945.

\subsection{The Military Intervention under UN Charter}

About the usage of force and threats in accordance with UN Charter Article 2, paragraph 4, are totally prohibited. "United Nations members are expected to refrain from threatening or employing force against political independence or any state's sovereignty, or in any other manner inconsistent with the goals of the United Nations in international affairs"9. A totally prohibition on usage of force and threats is counter to the political independence or any state's sovereignty. Also UN charter in Article 2, paragraph 3 necessitates national disputes to settle by "peaceful means" ${ }^{10}$, which considered as the main pillars of global system after the post-World War II. As stated in the UN Charter's Preamble, the international community stated its goal of creating a peaceful world so that to defend future generations from the scourge of war ${ }^{11}$. The UN Charter though contains two exemptions to this rule: collective or individual self-defence in reaction to an armed attack, as defined in Article 51 of the Charter, and UNSC-authorized the uses of force under Chapter VII of the Charter in Articles $39-54^{12}$ to reinstate and preserve international concord and safety ${ }^{13}$. These rules show that the use of military force is tolerable in particular cases and must be viewed as a legal exemption to the overall ban on the usage of force. Self-defence under UN Charter Article 51 or the UNSC's authorisation to use force under article $42^{14}$ are the exceptions here to the restriction. Additionally, states may allow another state to employ force in their territory such as against rebel or terrorist groups, in order to protect themselves. Sometimes, new interpretations of existing regulations or new exclusions emerge because of governmental practice.

\section{The Conceptual Framework of Military intervention}

\subsection{The Military Intervention Concept}

Rosenau was one of the earliest persons to express reservations concerning the idea of military intervention's inherent ambiguity. He traits the scantiness of "scholarly writings on the problem of in developing systematic knowledge on conditions under which military intervention behavior is initiated, sustained, and abandoned", mainly to scarcities in conceptualization ${ }^{15}$. In another opinion, Hermann and Kegley stretched Rosenau's worry about conceptual vagueness to conflicting understandings of military intervention, perceiving that the similar skirmish conduct can be characterized as military intervention, non-intervention, or other intervention, depending on distinct indexes ${ }^{16}$. In order to fully appreciate its contribution, having a clear definition of "just war" is critical to full understanding on how this idea might be applied to contemporary interventionist ethics. There have been numerous sorts of intervention throughout human history: political or military, direct or indirect. New types of military intervention have arisen as a result of the decease of the Cold War period because of the perpendicular volume of military activity.

As result the concept "intervention" becomes more complex to understand its meaning. According to Garrett, he summarised that instances of intervention give out nearly ceaselessly, and in significance he contends that, the notion has converted "inherently broad and protean"17. As a result, comprehending the meaning of the phrase "intervention" becomes more difficult. Garrett observes that examples of intervention are nearly endless, and as a result, he believed the idea has become "inherently vast and protean"18. Nevertheless, two main factors may be attributed to this: first, there is an ever-increasing variety of motivations for intervention; and second, non-state actors are becoming increasingly significant political players. Aside from globalization and developments in international media, the rise of new humanitarianism and aggressively political nongovernmental organizations (NGOs) are critical in the humanitarian sector ${ }^{19}$.

Woodhouse and Ramsbotham established a five-part typology in an effort to get direction to this definitional argument. Coercive governmental humanitarian intervention has military and non-military manifestations, which offer the first two kinds. Military and non-military forms of non-coercive governmental humanitarian assistance give the following two sorts of non-coercive humanitarian intervention. The remained types are non-governmental, intergovernmental and transnational humanitarian intervention ${ }^{20}$. In this regard as a follow-up to this analysis, Holliday proposed the creation of a larger typology of intervention than only humanitarian aid. This typology relies solely on the political component of intervention, and attempting to go beyond this would produce an almost uncontrolled level of complexity. This will push the boundaries of both the most contemporary interventionist thinking and just war tradition. When the key features of intervention are 
considered in this way, three are particularly significant and useful in developing a typology; the first is the temperament of the intervening agency, whether it is a non-state or a state; the second is the technique of intervention, whether non-coercive or coercive; and the third is the domain of intervention, whether it is internal or exterior to the target society. When these three conditions are fed into a matrix, eight different varieties are produced $^{21}$. Different types of international political involvement are depicted in Figure 3.1 below

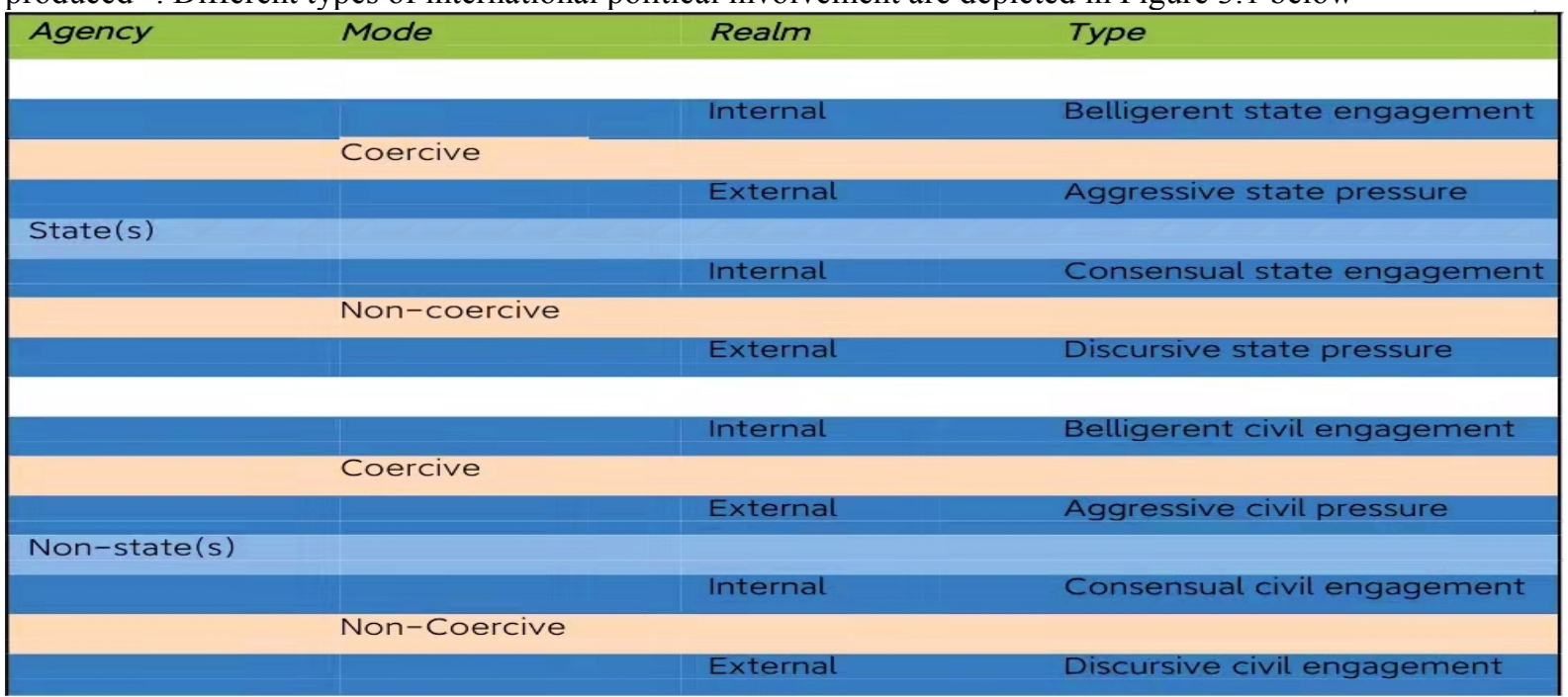

Figure 3.1: Classes of Interventions

There has been resurgence in "just war" thinking as a result of this heightened attention to the concept of military intervention (JWT). The JWT was mainly an anxiety for theologians and legal theorists in the twentieth century, with the former owing to its historical origins in Augustine and Aquinas' spiritual instruction, and the latter due to disagreements over the theory's efficacy in relation to a multinational authority and intercontinental law. In the formation of the JWT, St. Augustine $(354-430)$ claimed, "the justness of action could be judged without evaluating the driving intention, so also with the action of going to war" 22 .

\subsection{Patterns of Military Intervention}

It is the goal of this section to explain how military intervention has evolved since Cold War ended. To begin, ten historical patterns of military intervention will be clarified. In Ortega (2001), a variety of patterns have developed over time, but only ten of these historical examples will be used in this study (see figure 3.2 below) ) $^{23}$. To highlight the uncertainties that arise from the evolution of military intervention theory and practice across time, is the main reason for these interventions to be used in this study. In the next sections only a few types of interventions will be explored and referenced to.

\begin{tabular}{|l|l|}
\hline \multicolumn{1}{|c|}{ Historical } & \multicolumn{1}{c|}{ More Contemporary } \\
\hline Imperialistic intervention & Cold War pattern of intervention \\
Colonial Pattern of intervention & Humanitarian intervention \\
The Balance of power & Collective intervention \\
Ideological intervention & Punitive intervention \\
Self-determination & Pre-emptive intervention \\
\hline
\end{tabular}

Figure 3.2: Patterns of Interventions

Patterns of interventions are historically supplemented by a variety of normative norms that often arose. Intervening powers claim, with varied degrees of clarity and certainty, justification and validations for their conduct, whereas other governments use a variety of arguments to oppose interventions. As a result of these interactions, the international community has developed principles for intervening. This is obviously a set of broad legal rules, but they aren't just applicable in the legal sphere. Non-written definitions of the legal, political and moral underpinnings of international order at a specific time are what we mean by international principles. In this sense, they can be seen as both broad ideals and principles that are constantly changing.

It has constantly remained a dominant worth tied to state sovereignty, and the content of the latter has evolved in tandem with military intervention's evolution. There are four forms of the non-intervention concept that can be recognized. First, there is the ancient European ideal of non-intervention, which was formed for the European concert of countries from the sixteenth century and remained in effect until World War II. Second, there is legalistic principle of non-intervention which was developed under the auspices of the United Nations during the Cold War and was hailed as the extreme version of the former. Third, the notion of collective intervention evolved relatively recently, as a result of United Nations Security Council interventions, which we 
will be addressed in the sections of this paper. Last but not least, there is the "principle of limited intervention," which enables governments to employ armed force in other countries for humanitarian reasons as well as for the aims stated in the UN Charter, which is to maintain international harmony and safety ${ }^{23}$.

\section{Objectives of Military Intervention}

The military intervention undertaken by the international community to maintain peace and security or to stop mass violations of human rights was frequently erratic with the objectives of the intervention which brings lack of trustworthiness. All the objectives of military intervention are going to be discussed in this section together with the circumstances that may permit military intervention to guarding of collective security and civilians in conflict circumstances also the possible consequences of military interventions.

\subsection{Restoring and Maintaining International Harmony and Safety}

According to the principle of restoring and maintaining international harmony and safety, the UNSC has interfered in many circumstances. The UNSC is the main body that given full mandate by the United Nations Charter to oversee all matters concerning the peace and security ${ }^{24}$. Since 2001, to secure the international system from terrorist attacks has become a common notion among affiliates of the global community, also when the violations against human right like offences against humanity, genocide and ethnic cleansing occurs and a nation is impotent or disinclined to defend its residents, the obligation to defend collective security validates the right to interfere $^{25}$. Even when military action is involved, the UNSC bears this obligation as the UN's primary collective security body ${ }^{25}$. Therefore, the current trend to an understanding of collective security goes in the direction of a more comprehensive system of protection notwithstanding the restriction stipulated in UN Charter article 2(7), the system includes interfering in the states internal affairs in circumstances of offences against humanity like genocide and ethnic cleansing. The actions were taken by the UNSC on the premise of collective security and protect human rights has been subjects of controversies among different stakeholders as explained in the next sections. In recent years, the UNSC has been more prepared to act on this basis, most obviously in Bosnia, Kosovo, Somalia, Afghanistan, Iraq, Libya and later in Syria, and Yemen ${ }^{26}$.

\subsection{Protecting International Human Rights}

Determining when the safeguard of basic human rights permits for military intervention is a very challenging task. The humanitarian interventions are commonly authorized by the UNSC to prevent extensive distress among the citizen or residents. In order for military intervention to be considered proportional, the harm done must be with less weight compares to the harm it prevented, which is recognised as the "do no harm" principle. ""Do no harm" involves stepping back to consider the whole picture and minimize any negative consequences on the environment, economy or social fabric that a particular action might have ${ }^{27}$. Preventing the genocide of a massive population, specifically those belonging to a certain ethnic or religious group considered as one of the foremost specimens of when intervention is justified ${ }^{28}$. Military intervention can also be justified when there is stabbing on the right to life in general comprising but not limited to extrajudicial implementations of political prisoners, large-scale attacks against civilians and massacres,. Likewise, humanitarian intervention grounds are extended to right violations which are not subjected to torture.

\subsection{Military Intervention and $R 2 P$}

A rapid response to prevent genocide is essential, as ethnic cleansing and genocide in many instances happen in the initial stages of conflicts within the state. Even in cases where interventions to stop war immediately do not succeed, it can frequently minimize violence against citizens, as it compel potential offenders to redirect their resources and time away from the extermination of civilians and toward their own defence. Though it is significant to abide by and obey with the rules of international law, sometimes this cannot be-done from a moral considerations such as intervening to protect the world's most vulnerable people from heinous and gross abuses of state power without the approval of the Security Council. Legal scholar Thomas Franck correctly asserts that "international justice is better served by sometimes breaking the law rather than respecting it" and in support of this proposition, he references NATO's operation in Kosovo ${ }^{29}$.

Therefore, taking such a coercive military stance against countries that commit massive violations against human rights is necessary even if it violates the rules of law for some. After making all reasonable efforts to get the UNSC's authorisation, if this cannot be obtained and a full evaluation of whether action is suitable and capable of achieving the stated objectives, such intervention should take place without the UNSC's permission ${ }^{30}$. However, trying to obtain UN Security Council authorization should not be a process so long when it becomes clear to all Council members the legitimate objective of the intervention.

According to this view, in the first place states would ask authorization from the UNSC Council for military intervention, but when this cannot be-secured due to the stalemate facing the UNSC, this should not prevent humanitarian intervention to fulfil the $\mathrm{R}_{2} \mathrm{P}^{31}$. So that, there is a essential to try to link the gap between UNSC 
authorizations, which are rarely authorized in politically sensitive circumstances and violate the use of force principle when necessary in times of need. There's been a lot of progress made in the area of the R2P. The General Assembly accepted the principle in 2005, and the Security Council reaffirmed it unanimously in 2006, notwithstanding its shaky beginnings ${ }^{32}$. However, the principle continues to be challenged, especially due to its relationship with humanitarian intervention and the widespread assumption that its primary objective is to pave the way for unilateral military intervention to be legitimized.

\subsection{Guarantee Country's Security during Military Intervention}

The foremost interventions aim is to uphold international harmony and safety and protect civilians, the intervention may also aggravate the suffering of the citizens, particularly when the intervention is carried out inappropriately. Intervention may make civilians trapped between the fire of the warring factions and the fire of military intervention and siege, as is happening now in Yemen ${ }^{33}$, or instead, they could be left defenceless in the vacuum created by the overthrow of their nation's government, as it is happening now in Iraq ${ }^{34}$. Such issues started in 2003 during joint military intervention in Iraq, where the forces from USA and UK eventually found themselves not capable to guarantee the country's security after their invasion. Foreign forces in Iraq have failed to prevent the spread of looting and failed to protect the citizens from intolerant violence and the escalating insurrection to this day. This failure is resulted from the inherently of the military, military was not suitable to deal with security difficulties that arise during the military interventions, because the military fundamentally deficiencies the competences to adequately deal with mass population and lower levels of organized violence. These situations need qualified police forces to ensure the country's security in unstable environment after the military intervention. Police forces must also have military skills with an emphasis on the non-lethal use of force, because the police force is basically a mixture of the military and the police, and its role is to effectively neutralize violent situations ${ }^{35}$.

\section{Legality and Legitimacy of Military Intervention}

5.1 Legality of Military Intervention

UN Charter does not expressly allow direct or indirect military intervention to defend human rights by the United Nations or by any state. The basis of the UN Charter is non-interference in the internal affairs of any other country as stipulated in Article 2(4), even if the people of that country faced recognised massive human right violations. Conversely, since the after Cold War period, the UNSC has sanctioned the use of force within member states' boundaries on numerous occasions. Real example is the case of Somalia, in which the UNSC sanctioned the use of force in eradicating human right violence and famine ${ }^{36}$. In the case of Rwanda, the UNSC sanctioned the use of force to stop the genocide of one ethnic group by another ${ }^{37}$. Also in Haiti, the Security Council granted the authority to use force to abolish the systematic human rights violations and re-establish democracy $^{38}$. This also happened in the case of Libya, where the UNSC adopted Resolution of 1973 on 17 th March, 2011 authorizing the use of force in Libya to guard citizens from attacks, precisely in the Benghazi city located in eastern part, which Colonel Muammar Gaddafi reportedly said he would storm to end the revolution's offensive against his regime. We note from the cases of Somalia, Haiti, and Libya that subsequently the end of the cold war the UNSC has decided that humanitarian crises of states or internal human rights violations may be described as a "threat to international peace and security" and thus allow the UN to intervene by force under Chapter VII of the UN Charter.

\subsection{Legitimacy of Military Intervention}

\subsubsection{Right of Veto Power and Military Intervention}

When a state is committing human rights breaches or a threat to world peace and security that necessitates the deployment of armed action, the UN Security Council is unable to sanction military intervention because of the veto of a permanent member of the $\mathrm{UN}^{39}$. The use of military action is not legal under international law when the veto is invoked, and if it were, it would be illegal. States must choose either doing nothing or abide by international law and acting in ways that violate established norms in order to avert or end human suffering and reinstate international security and peace. It may happen that states take military action without the sanction of the UNSC and outside the UN collective security system. This may happen when a State determines that military action is required to avert an imminent danger to world harmony and safety or to put an end to continuing violation of global security and peace or to confront an unfolding humanitarian disaster. As a result of a lack of UN Security Council support, NATO bombarded Kosovo in 1999 to stop the ethnic cleansing that was taking place there ${ }^{40}$.

It is generally agreed that the exploit done by NATO was illegal as the UNSC didn't authorize the intervention and cannot be regarded as self-defence action. Though, it was deemed a legitimate use of force due on the basis of preventing the continuation of massive human rights violations. According to the eminent legal scholar Antonio Cassese, he said of the matter "From a moral point of view, the resort to armed force was 
justified". However I cannot avoid that this moral act is inconsistent with existing international law"41. Selfgoverning International Commission on Kosovo decided that the action was illegal but acceptable based on a growing worldwide moral consensus ${ }^{42}$. Although NATO's operation was illegal at the time, the fact that no one publicly protested it suggests that most people agreed that it was the right thing to do at the time, even if it violated international law.

5.2.2 The Effect of Illegal Military Interventions on International Law

We must be careful not to violate the potential implications of an essential tenet of international law that forbids the usage of force contrary to sovereign states if we defend military intervention on moral grounds. International law is founded on the principle of reciprocity and the recognition of mutual obligation, and is recognized by states as binding in their relations with one another. Consequently, it is also possible that governments may opt not to adhere to an essential principle of international law such as non-use of force if it loses its authority and credibility ${ }^{43}$. When the scoundrel states act in violation of international law, whichever violation is probable to be viewed by the international community as illegal and unjustified. Nevertheless, when the violation of international law is by states that have political, legal and moral authority in the international arena, there is concern that other states will make the same act. This concern is due to the fact that it may eventually result to the regular fragmentation of the global system and a return to a world order regulated by political considerations. In addition to that and dissimilar local law, international law can be-amended or formed as the outcome of government practice. Thus, there must be a new customary norm of international law in order for it to be formed "evidence of general practice accepted as law"43. The concern basis is that violations of international law are one way to bring changes in the law. Therefore, in another word it can be explained as, if countries intervene external structure of the UN and under the auspices of (R2P). It will be possible to establish a legal basis for future intervention, in order for military intervention to be a legal omission to the ban on the use of force, there must be sufficient governmental practice and adequate countenance of the opinion that military intervention is a legal exemption.

\subsubsection{The obligations of International Criminal Court}

The international community has long felt the requirement for a global criminal court proficient of impeaching and gruelling those accountable for offenses of international anxiety, like genocide, offenses against humanity and war offences. The International Criminal Tribunals for Rwanda ("ICTR") 44 and Yugoslavia ("ICTY") 45 , which were established specifically in 1994 and 1993, were set up to work with murders committed in these two nations These two tribunals have pointed-out the necessity for a stable international criminal court to respond quickly and effectively with abuses of this nature. Therefore, the ICC formed to be the first self-governing and stable criminal court to contribute to the abolition of exemption for offenders of the supreme heinous offences about the global community. The ICC prosecutes only those accused of the most heinous offences, including genocide, offences against humanity and war offences. Due to the Kampala modifications, the ICC will refrain from intervening and acting as a court of last resort if a matter is being investigated by a domestic judicial system, except the local procedures are not genuine ${ }^{46}$.

Awkwardly not all countries recognize the authority of the ICC. The ICC's Rome Statute has 123 signatories as States Parties. There are 19 Asian-Pacific states, 28 Caribbean and Latin American states, 18 Eastern European states, 33 African states, and 25 Western European and other states. Though, the United States, one of the world's most important countries, has declined to ratify the Rome Statute so far. Russia, Israel, China and India are among the countries that have not joined the ICC ${ }^{47}$. The ICC's legitimacy and operational efficacy are both weakened by the absence of these significant players in the ICC's community. Additionally, the Court has been criticized in the past of failing to provide necessary balance and checks and of failing to sufficiently protect the rights of suspect individuals. The most devastating accusation so far has been the claim that the (ICC) is a tool of Western imperialism because of its biased and selective enforcement.

Regardless of all criticisms, the presence of a self-governing international organization, which can grasp the committers of the most serious crimes to account, is critical to the decline of military interventions. International justice becomes even more vital in the absenteeism of a country government prepared to grasp committers accountable. An individual state's inability to or unwillingness to conduct an investigation into war offences and offences against humanity necessitates judicial involvement from the international community. When it comes to its legitimacy and operational efficacy as well as other critiques, the ICC should be strengthened.

\section{Conclusions}

The idea of state sovereignty becomes moved away from the absolute conception where the state is the sole controller of its internal affairs. Therefore, where a state fails to discharge its responsibilities the international community is required to react and take the necessary steps, which may ultimately include the use of military force, to restore international peace and security, or to prevent gross human rights violations from occurring. There are exists a clear tension between the principle of non-interference in a state's internal affairs, and restoring international peace and security, and the promotion and protection of human rights. This is a tension, 
which has not been fully reconciled by the international community, and this is reflected by the wide-ranging disagreements about, and criticism of, the current state of the legal framework of military intervention in international law. According to our analysis, military action should not be taken carelessly or without careful examination of the legal position, as shown by above analysis of the legal and conceptual context. The advantages and disadvantages of Interference, operating capacity, and planning considerations should be taken. When considering a military intervention, it is critical that the intervening state weighs the potential impact on the ground against the impact of not interfering. Both the customary international law and UN Charter bind all world state. International law prohibits any use of force that goes beyond the boundaries of these legal principles. There is little room for legal involvement currently because of the strict norms governing the use of force in international law. Though, it is still perceived as legitimate in numerous situations, such as upholding international harmony and safety from imminent danger or egregious and massive human rights violations. The legal framework of military intervention should be taken seriously with a comprehensive legal study to determine the type of conflict, the legal position on the intervention, and the importance of planning issues.

\section{References}

[1] FS Pearson, RA Baumann, 1993, International military intervention, 1946-1988. https://doi.org/10.3886/ICPSR06035.v.

[2] M Ortega, Military intervention and the European Union, 2001, P.5.

[3] Karin von Hippel. Democracy by Force US Military Intervention in the Post-Cold War World, 2000, P.3.

[4] Dennis J. Dunn: A History of Orthodox, Islamic, and Western Christian Political Values- 2016, p.1- 9.

[5] H. H. W. HALLECK: Elements of International Law and Laws of War-1866, p.20-21.

[6] Ian Brownie: International Law and the Use of Force by States-1981, pp. 49-50.

[7] The General Treaty for the Renunciation of War1928. https://iilj.org/wp-content/uploads/2016/08/GeneralTreaty-for-the-Renunciation-of-War-Kellogg-Briand-Pact.pdf.

[8] James Crawford: Principles of Public International Law, 2019, PP.717- 745.

[9] The UN Charter Article 2 (4).

[10] The UN Charter Article 2 (3).

[11] Charter of the United Nations and Statute of the International Court of Justice; United Nations Publications, Mar 31, 2015 - Law - 128 pages.

[12] The UN Charter Article 51

[13] The UN Charter Articles 39-54.

[14] The UN Charter Article 42: "Should the Security Council consider that measures provided for in Article 41 would be inadequate or have proved to be inadequate, it may take such action by air, sea, or land forces as may be necessary to maintain or restore international peace and security. Such action may include demonstrations, blockade, and other operations by air, sea, or land forces of Members of the United Nations."

[15] ROSENAU, J.M. Intervention as a scientific concept. Journal of Conflict Resolution, Vol.12, No.2, 1969, p.149.

[16] MG Hermann, CW Kegley Jr - Journal of Conflict Resolution. Ballots, a barrier against the use of bullets and bombs: Democratization and military intervention, 1996, P.244. https:/www.jstor.org/.

[17] Garrett, S.A. Doing Good and Doing Well: An Examination of Humanitarian Intervention. Westport, CT: Prager, 1999, p.3.

[18] Korey, W. NGOs and the Universal Declaration of Human Rights: 'A Curious Grapevine'. New York: St Martin's Press, 1998.

[19] RAMSBOTHAM, O. Humanitarian Intervention 1990-1995: A Need to RECONCEPTUALIZE? Review of International Studies, Vol.23, 1997, p.112; RAMSBOTHAM, O. and Woodhouse, T. Humanitarian Intervention in Contemporary Conflict: A Reconceptualization. Cambridge: Polity Press, 1998, pp.225-231.

[20] Holliday, I. Ethics of Intervention: Just War Theory and the Challenges of the 21 st Century, International Relations, Vol.17, No.2, 2003, p.121.

[21] Ian Holliday, 'When Is a Cause Just?', Review of International Studies 2002, 28: pp.557-75

[22] MUSHKAT, R. The Concept of Just War in International Law, LLD Thesis, UNISA, 1986, p. 278.

[23] Ortega, M. Military Intervention and the European Union. Institute for Security Studies of Western European Union, CHAILLOT Paper 45, 2001, p.5.

[24] R Gordon - Mich. J. Int'l L., 1993: United Nations Intervention in Internal Conflicts: Iraq, Somalia, and Beyond, Volume 15 Issue 2- 1994. https://repository.law.umich.edu/.

[25] International Commission on Intervention and State Sovereignty (ICISS) Report of the International Commission on Intervention and State Sovereignty-December 2001, p 57-66; Ruth Gordon: United Nations Intervention in Internal Conflicts: Iraq, Somalia, and Beyond, 1994, Volume 15 Issue 2

[26] Repertoire of the Practice of the Security Council 20th Supplement, 2016-2017 Department of Political 
Affairs - Security Council Affairs Division Security Council Practices and Charter Research Branch.https://www.un.org/securitycouncil/sites/www.un.org.securitycouncil/files/part_vii_final_for_webp osting.pdf.

[27] Bass, Gary J. Freedom's Battle: The Origins of Humanitarian Intervention. New York: Random House, 2008.

[28] ND White Melbourne, Defending humanity: when force is justified and why by George P Fletcher and Jens David Ohlin, 2009. https://nottingham-repository.worktribe.com/.

[29] Thomas M. Franck, "Who Killed Article 2 (4)? Or: Changing Norms Governing the Use of Force by States", American Journal of International Law 64 (1970) 810 in Ian Hurd, "Is Humanitarian Intervention Legal? The Rule of Law in an Incoherent World", Ethics and International Affairs, 25 no. 3 (2011) pp. 293-313.

[30] J Morris - Libya and Syria: R2P and the spectra of the swinging pendulum, International Affairs, 2013. https://onlinelibrary.wiley.com/.

[31] B Simma. NATO, the UN and the Use of Force: Legal Aspects, 1999. https://watermark.silverchair.com/100001.pdf.

[32] On 28 April 2006, the Security Council unanimously adopted Resolution 1674 on the Protection of Civilians in Armed Conflict. Resolution 1674 contains the first official Security Council reference to the Responsibility to Protect. On 11 November 2009, during its eighth debate on the POC, the Security Council adopted Resolution 1894, in which where Member States expressed a continued commitment to RtoP; Bellamy, Alex J. (2009). Responsibility to protect: the global effort to end mass atrocities. Polity. p. 133. ISBN 978-0-7456-4347-2.

[33] World Report 2020, Yemen Events of 2019; Children attending class on the first day of school, which was damaged by an airstrike during fighting between Saudi-led coalition-backed government forces and Houthi forces, Tazi, Yemen, September 3, 2019. https://www.hrw.org/world-report/2020/country-chapters/yemen.

[34] Michael E. O'Hanlon Saturday, January 1, 2005; Iraq without a Plan, https://www.brookings.edu/articles/iraq-without-a-plan/.

[35] S Hoffmann - Survival, - The politics and ethics of military intervention, 1995 Pages 29-51| published online: 03 Mar 2008. https://doi.org/10.1080/00396339508442814.

[36] On 3 December, the Security Council adopted, unanimously, its resolution 794 authorizing the use of "all necessary means to establish as soon as possible a secure environment for humanitarian relief operations in Somalia",1992.

[37] S/RES/965 (1994), UN Assistance Mission for Rwanda; S/RES/955 (1994), Establishment of the International Criminal Tribunal for Rwanda (ICTR) and adoption of the Statute of the Tribunal.

[38] UNSC 940, adopted on 31 July 1994, the Council permitted a United States-led force to restore President Jean-Bertrand Aristide and authorities of the Government of Haiti, and extended the mandate of the United Nations Mission in Haiti (UNMIH) for an additional six months.

[39] RA Falk - American Journal of International Law, 1999. Kosovo, world order, and the future of international law. https://www.jstor.org/; See also, VP Nanda - Mich. St. U. Coll. L. Int'l L. Rev., 2013. The future under international law of the responsibility to protect after Libya and Syria. https:/hcommons.org/deposits/download/hc:35362/CONTENT/fulltext.pdf/.

[40] Ramesh Thakur, Charles SAMPFORD· Responsibility to Protect and Sovereignty-2016, P.176.

[41] Antonio Cassese. Are we moving towards international legitimation of forcible humanitarian countermeasures in the world community?' (1999), European Journal of International Law 23 at 25.

[42] Independent International Commission on Kosovo, Kosovo Report: Conflict, International Response, Lessons Learned (2000), P.164.

[43] Emmanuel ROUCOUNAS· A Landscape of Contemporary Theories of International Law-2019, P.310.

[44] United Nations; International Residual Mechanism for Criminal Tribunals Legacy website of the International Criminal Tribunal for Rwanda. https://unictr.irmct.org/en/tribunal.

[45] United Nations | International Residual Mechanism for Criminal Tribunals; International Criminal Tribunal for the former Yugoslavia1993 - 2017. https://www.icty.org/.

[46] WA Schabas, An introduction to the international criminal court, 2011. https://d1wqtxts1xzle7.cloudfront.net/.

[47] R Villacis. Working Methods of the Assembly of States Parties to the Rome Statute- International Criminal Law Review, 2018

\section{Acknowledgment}

I express special thanks to the Chinese Scholarship Council (CSC) for supporting my PhD studies. Also I would like to express extremely gratitude to my supervisor Professor Maming Fei for his advice, encouragement and guidance in this research. Moreover, I admit and consider all organisation and individuals who helped me in one way or another toward the success of this research, in general I thank you all. 